\title{
T Lymphocyte Recruitment by Interleukin-8 (IL-8) IL-8-induced Degranulation of Neutrophils Releases Potent Chemoattractants for Human T Lymphocytes Both In Vitro and In Vivo
}

\author{
Dennis D. Taub, ${ }^{\star}$ Miriam Anver, ${ }^{\ddagger}$ Joost J. Oppenheim, ${ }^{\S}$ Dan L. Longo, and William J. Murphy ${ }^{\llbracket}$ \\ *Clinical Services Program, "Biological Carcinogenesis and Development Program, and ${ }^{\ddagger}$ Pathology Histotechnology Laboratory, \\ SAIC-Frederick; ${ }^{\S}$ Laboratory of Molecular Immunoregulation, Frederick Cancer Research and Development Center-National Cancer \\ Institute; and ${ }^{\|}$Office of the Scientific Director, National Institute on Aging, Baltimore, Maryland 21702
}

\begin{abstract}
IL-8 has been shown to be a human neutrophil and $\mathrm{T}$ cell chemoattractant in vitro. In an effort to assess the in vivo effects of IL-8 on human leukocyte migration, we examined the ability of rhIL-8 to induce human T cell infiltration using a human/mouse model in which SCID mice were administered human peripheral blood lymphocytes intraperitoneally, followed by subcutaneous injections of rhIL-8. rhIL-8 induced predominantly murine neutrophil accumulation by $4 \mathrm{~h}$ after administration while recombinant human macrophage inflammatory protein-1 $\beta$ (rhMIP-1 $\beta$ ) induced both murine monocytes and human $T$ cell infiltration during the same time period as determined by immunohistology. Interestingly, $72 \mathrm{~h}$ after chemokine administration, a marked human $T$ cell infiltrate was observed in the IL-8 injection site suggesting that rhIL-8 may be acting indirectly possibly through a murine neutrophil-derived $\mathrm{T}$ cell chemoattractant. This hypothesis was confirmed using granulocyte-depleted SCID mice. Moreover, human neutrophils stimulated in vitro with IL-8 were found to release granulederived factor(s) that induce in vitro $T$ cell and monocyte chemotaxis and chemokinesis. This $T$ cell and monocyte chemotactic activity was detected in extracts of both azurophilic and specific granules. Together, these results demonstrate that neutrophils store and release, upon stimulation with IL-8 or other neutrophil activators, chemoattractants that mediate $\mathrm{T}$ cell and monocyte accumulation at sites of inflammation. (J. Clin Invest. 1996 97:1931-1941.) Key words: chemotaxis • T lymphocytes • neutrophils • granules
\end{abstract}

\section{Introduction}

IL-8 is an 8400-dalton protein, that was recently isolated, sequenced, and cloned (1-4). IL-8 is synthesized and secreted by LPS-stimulated monocytes, macrophages, and by numerous other nonleukocytic cell types, including epithelial and endo-

The contents of this publication do not necessarily reflect the views or policies of the Department of Health and Human Services, nor does mention of trade names, commercial products, or organizations imply endorsement by the U.S. Government.

Address correspondence to Dr. Dennis D. Taub, Clinical Services Program, SAIC-Frederick, Frederick Cancer Research and Development Center-National Cancer Institute, Bldg 560, Rm 11-23, Frederick, MD 21702-1201. Phone: 301-846-1491; FAX: 301-846-6022.

Received for publication 13 September 1995 and accepted in revised form 22 December 1995.

The Journal of Clinical Investigation

Volume 97, Number 8, April 1996, 1931-1941 thelial cells, lymphocytes, fibroblasts, and keratinocytes (4-7). IL-8 is produced in response to a number of noxious or infectious stimuli including LPS, zymosan, IL-1, and TNF $\alpha$ (4-6). IL-8 was initially identified as a chemoattractant for neutrophils but not monocytes $(1,2)$. This view is supported by the detection of IL-8 at inflammatory sites characterized by neutrophil infiltration (8-15). IL-8 has also been shown to activate neutrophils in inflammatory sites $(4-6,16,17)$. Several laboratories have shown that IL- 8 induces rapid neutrophil degranulation permitting the release of specific granule enzyme contents into the culture supernatants $(4-6,18,19)$.

$\mathrm{T}$ lymphocytes have also been reported to migrate in response to IL-8 both in vivo and in vitro (4-6, 20-24). However, because the ability of IL- 8 to induce $T$ cell migration has been a point of controversy $(5,24)$, we have investigated the effects of rhIL-8 on human T cell migration in vivo in SCID mice reconstituted with human peripheral blood T lymphocytes. Further in vitro analysis of this effect has determined that IL-8 activates neutrophils to release prestored chemotactic products from their granules that mediate the in vitro migration of human T lymphocytes.

\section{Methods}

Mice. C.B-17 scid/scid (SCID) mice were obtained from the Animal Production Area, NCI-FCRDC (Frederick, MD). Mice were used at $8-12$ wk of age and were kept under specific pathogen-free conditions (25). The SCID mice were housed in microisolator cages, and all food, water, and bedding were autoclaved before use. SCID mice received $40 \mathrm{mg}$ of trimethoprim and $200 \mathrm{mg}$ of sulfamethoxazole per $320 \mathrm{ml}$ of drinking water.

Cells. The human peripheral blood $\mathrm{T}$ cells were prepared using PMBCs from normal donor obtained by leukopheresis (26). Donors provided informed consent. PBMC were passaged over FicollHypaque to remove erythrocytes, granulocytes, and cellular debris. T cells and $T$ cell subsets were then purified using a modified procedure using R\&D T cell and T cell subset enrichment columns (R\&D System, Minneapolis, $\mathrm{MN})$. Viable cells isolated from the $\mathrm{F} / \mathrm{H}$ interface $\left(1 \times 10^{7}\right.$ cells $\left./ \mathrm{ml}\right)$ were subsequently incubated at $4^{\circ} \mathrm{C}$ with $10 \mu \mathrm{g} / \mathrm{ml}$ anti-CD16 antibody for $30 \mathrm{~min}$, and then passaged over an R\&D System T-cell enrichment column. Preincubation of PBMCs with antiCD16 antibody facilitates the removal of NK cells from the T cell preparations. This isolation procedure typically yielded $>95 \%$ motile $\mathrm{CD}^{+} \mathrm{CD}^{-} 4^{-} \mathrm{CD} 19^{-} \mathrm{CD}^{-} 6^{-} \mathrm{CD}^{-} 6^{-}$lymphocytes. Similarly, $\mathrm{CD}^{+}$and $\mathrm{CD}^{+} \mathrm{T}$ cell subsets were also isolated using $\mathrm{R} \& \mathrm{D}$ System $\mathrm{T}$ cell subset columns following the manufacturer's instructions and typically yielded $>98 \%$ purified T cell subpopulations. The contaminating cell populations in the $\mathrm{T}$ cell and $\mathrm{T}$ cell subset preparations were negative for CD14, CD16, CD19, and CD56 markers and therefore did not include NK cells, monocytes, or B cells.

Human neutrophils were isolated by previously described methods (2). Briefly, erythrocytes were removed by sedimentation with $1.5 \%$ dextran, mononuclear cells were removed by Ficoll-Hypaque, and residual red blood cells were lysed using hypotonic lysis. The pu- 
rity of the isolated neutrophils was assessed by differential analysis using Wright's stain and was generally $\geq 98 \%$ neutrophils. However, in some neutrophil preparations, $0-2 \%$ human eosinophils were copurified. This may account for the enhanced degranulating effects of IL-8 on VCAM-1-coated plates using neutrophil preparations as human neutrophils do not bear VLA-4 receptors.

Human monocytes were isolated from peripheral blood mononuclear cells using a discontinuous Percoll gradient to separate monocytes from the various lymphocytic populations. Typically, $>90 \%$ enriched monocytes were isolated using this technique as confirmed by FACS analysis and esterase staining.

Murine neutrophils were isolated through the i.p. injection of 1.5 $\mathrm{ml}$ of protease peptone in BALB/c mice and harvesting the generated peritoneal fluid $4 \mathrm{~h}$ later. The peritoneal exudate cells derived by this method contain up to $49 \%$ neutrophils. The cells were subsequently treated with $1.5 \%$ dextran to remove erythrocytes and FicollHypaque to remove mononuclear cells. Residual red blood cells were lysed using hypotonic lysis. The purity of the isolated neutrophils was assessed by differential analysis using Wright's stain and was generally $\geq 94 \%$ neutrophils.

In vivo studies and generation of huPBL-SCID mice. All mice received $20 \mu \mathrm{l}$ of $\alpha$ ASGM1 i.v. $1 \mathrm{~d}$ before human cell injection (antiASGM1, Wako Chemicals, Dallas, TX), which we previously found to improve human cell engraftment through the abrogation of SCID NK activity (25). HuPBL for transfer experiments were obtained from healthy donors in leukopaks. All donors were screened for HIV-1 and hepatitis B before donation and signed informed consents. The huPBL were then elutriated by counter-current elutriation to remove monocytes and fractions containing $>90 \%$ of lymphocytes were used (25). The cells were then counted on a Coulter Counter (Coulter Electronics, Hialeah, FL) and $1 \times 10^{8}$ huPBL were injected i.p. into SCID recipients. Immediately after huPBL injection, rhIL-8, or rhMIP-1 $\beta$ ( $1 \mu \mathrm{g}$ in $0.1 \mathrm{ml}$ PBS) or $0.1 \mathrm{ml}$ PBS was injected s.c. in the SCID mice. Mice were either assayed 4 or $72 \mathrm{~h}$ after daily injection. The 4 and $72 \mathrm{~h}$ time point was selected after a series of kinetic histological analyses to examine maximal infiltration into the injection site post immunization. $4 \mathrm{~h}$ was optimal for acute leukocyte recruitment while $72 \mathrm{~h}$ was optimal for the more chronic lymphocyte recruitment. In addition, several concentrations of IL- 8 and MIP-1 $\beta$ were tested in this model, including $100 \mathrm{ng}, 1 \mu \mathrm{g}$, and $10 \mu \mathrm{g}$. In all cases, injection of higher doses $(10 \mu \mathrm{g})$ of rhIL- 8 resulted in a less potent infiltration into the injection site (data not shown). For the granulocyte depletion experiments, SCID mice received the anti-granulocyte antibody, 8C5 (purified ascites) $0.2 \mathrm{mg}$ i.p. for $2 \mathrm{~d}$ before huPBL transfer. Experiments contained 3-5 mice per group and were performed four times using different huPBL donors with representative experiments being shown.

Histology. Injection sites from one to three mice per experimental group were mixed in $10 \%$ neutral buffered formalin, embedded in paraffin, sectioned at $5 \mu \mathrm{m}$ and stained with hematoxylin and eosin (H\&E). Slides were evaluated microscopically without knowledge of the experimental treatment.

Immunohistochemistry. Skin injection sites and the underlying body wall were embedded in O.C.T. compound tissue medium (Baxter Health Care Corp., Charlotte, NC), snap-frozen on dry ice and stored at $-70^{\circ} \mathrm{C}$ until sectioning. Tissues were then sectioned on a cryostat at $5 \mu \mathrm{m}$. Before staining, tissue sections were warmed to room temperature, fixed for $10 \mathrm{~min}$ in acetone, and rinsed in PBS. The following primary mouse DAKO antibodies (Dako Corporation, Carpenteria, CA) were used: DAKO-CD3, T3-4B5 (normal human blood T lymphocytes); DAKO-CD4, MT310 (CD4 helper/inducer lymphocytes); DAKO-CD8 and DK25 (CD8 cytotoxic/suppressor T lymphocytes).

Dilutions of antibody were 1:150,1:40, and 1:30, respectively; incubation time was $30 \mathrm{~min}$. The avidin-biotin complex (ABC) method was used with the mouse ABC Vectastain Elite Kit (Vector Laboratories, Burlingame, CA) as the secondary antibody and 3,3' diaminobenzidine as the chromogen. Mayer's hematoxylin was used as a counter-stain. An injection site negative control (mouse Elite kit and no primary antibody) and a positive control (pelleted normal human lymphocytes) were included for each sample run. We have previously found that the anti-human $\mathrm{CD} 3 \mathrm{mAB}$ did not bind either SCID splenocytes or subcutaneous tissues (37-38).

Injection sites were evaluated microscopically without knowledge of the experimental treatment. Immunostaining was graded from minimal $(1+)$ to extensive $(4+)$ based on intensity and distribution of positive cells.

Chemokines and antibodies. The chemokines IL-8, RANTES, MCP-1, and MIP-1 $\beta$ were expressed in E. coli and fresh batches were purchased from Pepro Tech, Inc. (Rocky Hill, NJ). Anti-MIP-1 $\alpha$, -MIP-1 $\beta$, -RANTES, -IL-8, and -MCP-1 antisera were obtained from R\&D Systems (Minneapolis, MN). These antibodies have been shown to be specific and noncross-reactive (D. Taub, data not shown).

Chemotaxis assay. Neutrophil and monocyte migration were quantified using a modification of the Boyden chamber technique (27). Briefly, PMN and monocytes were suspended at $2 \times 10^{6} \mathrm{cells} / \mathrm{ml}$ in RPMI 1640 plus $0.5 \%$ BSA, and were placed in the top wells of a 48-well microchemotaxis chamber. The upper and lower wells were separated by a $5-\mu \mathrm{m}$ pore size polycarbonate filter (Neutrophils, PVP-free; Monocytes, PVP) that separated the cells from the control and experimental samples in the bottom wells. Neutrophil migration assays were incubated for $30 \mathrm{~min}$ at $37^{\circ} \mathrm{C}$ in a $5 \% \mathrm{CO}_{2}$ moist atmosphere, while monocyte chemotaxis assays were incubated for $90 \mathrm{~min}$ at $37^{\circ} \mathrm{C}$. The filters were then washed to remove non-migrating cells from the upper surface. Filters were subsequently fixed in methanol and stained with Diff-Quik, and the number of migrating cells per high-powered field were counted for each well. The results represent the average number of migrating cells per high power field ( \pm SD).

T-cell migration was quantitated as previously described $(27,28)$. $\mathrm{T}$ cells were suspended at $10^{7}$ cells $/ \mathrm{ml}$ in RPMI containing $0.5 \% \mathrm{FCS}$, and were placed in the top wells of a 48-well microchemotaxis chamber. The upper and lower wells were separated by a $5-\mu \mathrm{m}$ pore size polycarbonate filter that separated the cells from the control and experimental samples in the bottom wells. All polycarbonate filters used were coated with human plasma fibronectin $2 \mathrm{~h}$ before use in the assay (29). The chambers were incubated for $4 \mathrm{~h}$ at $37^{\circ} \mathrm{C}$ in a $5 \% \mathrm{CO}_{2}$ moist atmosphere, and the filters were washed to remove nonmigrating $\mathrm{T}$ cells from the upper surface. Filters were subsequently fixed and stained as described above. The results represent the average number of migrating cells per high powered field $( \pm S D)$.

Neutrophil granule preparations. After neutrophil isolation, neutrophil granules were separated by continuous sucrose gradients as initially described by West et al. (30) and Wright et al. (31). PMNs were washed several times in PBS $\left(\mathrm{Mg}^{2+} / \mathrm{Ca}^{2+}\right.$-free) to remove residual serum components and Ficoll-Hypaque from the suspension. The PMNs were then lysed by resuspending the cells in a lysis buffer containing $0.25 \mathrm{M}$ sucrose, $10 \mathrm{mM}$ Hepes ( $\mathrm{pH} 7.4)$, and $4 \mathrm{mM}$ EGTA followed by nitrogen cavitation. Nuclei and debris were removed by centrifugation at $600 \mathrm{~g}$ for $15 \mathrm{~min}$ or passage through both 5 and $2 \mu \mathrm{m}$ polycarbonate filters. Resulting granule-rich lysates were then layered over $48 \%$ Percoll and centrifuged at $30,000 \mathrm{rpm}$ for $30 \mathrm{~min}$. The granules were recovered from the Percoll fractions, pooled, and tested for enzymatic activity. Dense granules were solubilized in 10 $\mathrm{mM}$ Hepes, $2 \mathrm{M} \mathrm{NaCl}$ ( $\mathrm{pH}$ 7.4) and then subjected to two rapid freeze-thaw cycles using dry ice in $95 \%$ ethanol and a $37^{\circ} \mathrm{C}$ waterbath. The mixture was centrifuged at $100,000 \mathrm{~g}$ for $3 \mathrm{~h}$ to remove insoluble material. The supernatant was frozen in small aliquots at $-70^{\circ} \mathrm{C}$ and then used in experiments as a crude granule extract.

For the enrichment of azurophilic and specific neutrophil granules, non-lysed neutrophil granule preparations $(5 \mathrm{ml})$ were layered over continuous sucrose gradients with specific gravities ranging from 1.12 to 1.28 in cellulose nitrate centrifuge tubes, then centrifuged at $100,000 \mathrm{~g}$ for $4 \mathrm{~h}$ at $4^{\circ} \mathrm{C}$. After centrifugation, gradients were pumped out at $1 \mathrm{ml} / \mathrm{min}$ through the bottom of the centrifuge tube and 1.4-ml fractions were collected for enzyme determinations. Previous reports using this technique have revealed that three granule fractions and a 

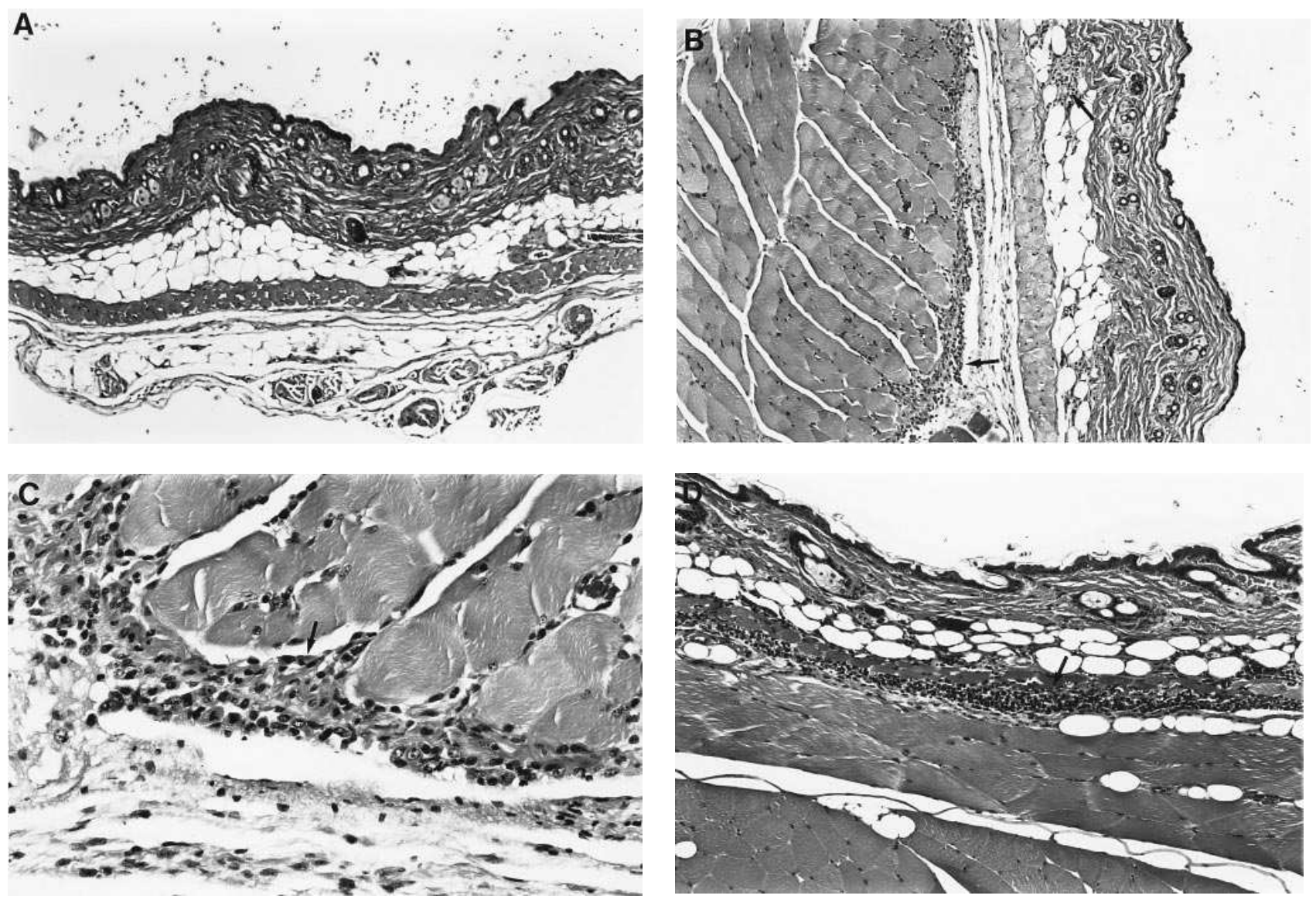

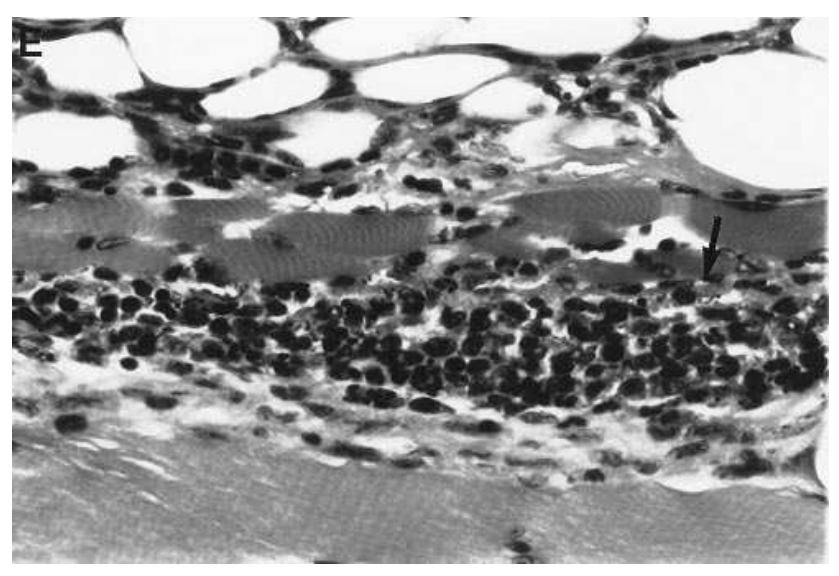

particulate fraction that contain enzymes characteristic of plasma membrane can be obtained. The granules have been labeled 1,2, and 3 and it has been shown that granules 1 and 2 correspond to azurophilic granules and 3 to the specific granules (32). The various granule fractions were assessed for protein levels, enzyme levels, and were subsequently pooled, diluted in $0.34 \mathrm{M}$ sucrose, pelleted by centrifugation at $27,000 \mathrm{~g}$ for $25 \mathrm{~min}$, washed twice in PBS, repelleted and then lysed by three freeze-thaw cycles as described above.

Measurement of azurophilic and specific granule release. Determination of the amount of lactoferrin (LF) released by neutrophils was performed with cell supernatants after IL-8, FMLP, or PMA exposure for 4-6 $\mathrm{h}$ in a serum-free medium. The assay used was an enzyme-linked immunosorbent assay described in detail elsewhere (33). The results are presented as nanomoles of lactoferrin per $10^{6}$ PMNs.
Figure 1. Injection site of huPBL-SCID mice 4 or $72 \mathrm{~h}$ after IL-8 administration. $(A)$ Control (huPBL and s.c injections of HBSS). No cellular infiltrate observed $4 \mathrm{~h}$ after injection (H\&E, 25×). (B) rhIL-8 $4 \mathrm{~h}$ after injection. Cellular infiltrate in dermis and subcutis (arrows). (H\&E, $33 \times)$. (C) rhIL-8 $4 \mathrm{~h}$ after injection. Neutrophils (arrows) in cellular infiltrate $(\mathrm{H} \& \mathrm{E}, 132 \times) .(D)$ rhIL-8 $72 \mathrm{~h}$ after injection. Cellular infiltrate (arrow) in subcutis and flank muscle (H\&E, 25×). (E) rhIL-8 $72 \mathrm{~h}$ after injection. Infiltrate is primarily mononuclear cells (long arrow) with foci of neutrophils. (H\&E, 80×).

The levels of $\beta$-glucuronidase ( $\beta$-GLU) were measured as previously described (34). Briefly, the level of $\beta$-glucuronidase was determined in $0.1 \mathrm{M}$ sodium acetate buffer ( $\mathrm{pH} 4.4$ ) with $0.001 \mathrm{M}$ phenolphthalein glucuronic acid (Sigma Chemical Co., St. Louis, MO) and $0.5 \mathrm{mg}$ of protamine sulfate. Samples were covered and incubated for $24 \mathrm{~h}$ at $37^{\circ} \mathrm{C}$. Chromagen was read at $540 \mathrm{~nm}$ and expressed as $\mu \mathrm{g}$ phenolphthalein released per hour per milliliter.

Lactic dehydrogenase (LDH) was assayed according to the method of Wroblewski et al. (35) and was expressed as milliunits per milliliter.

Myeloperoxidase (MPO) was determined by a modification of the $o$-toluidine method by Baggiolini et al. (36). Chromagen was allowed to develop for $6 \mathrm{~min}$ after the addition of $100 \mu \mathrm{l}$ of sample and stopped by the addition of $50 \% \mathrm{NaOH}$. Horseradish peroxidase 

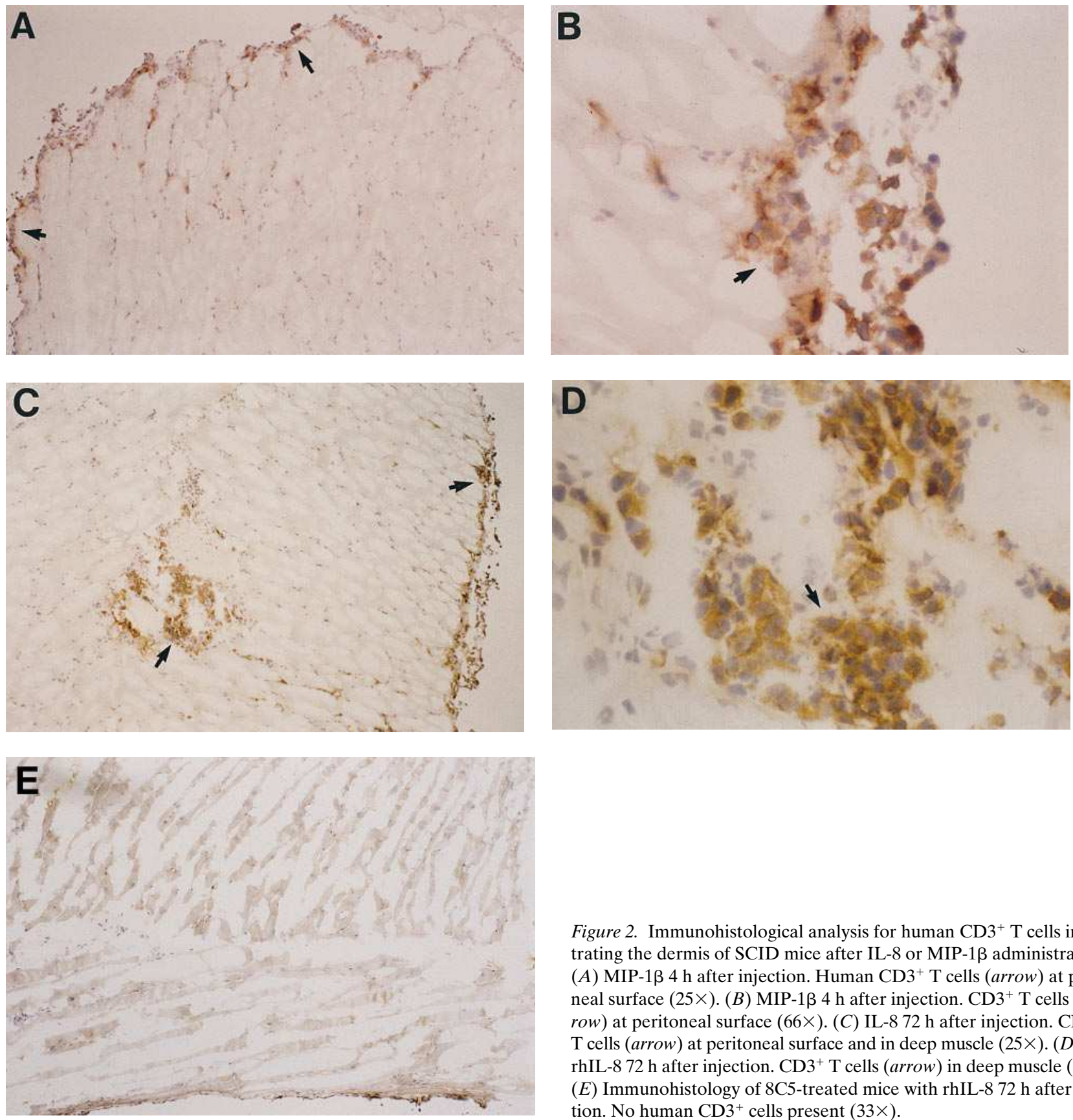

Figure 2. Immunohistological analysis for human $\mathrm{CD}^{+} \mathrm{T}$ cells infiltrating the dermis of SCID mice after IL- 8 or MIP- $1 \beta$ administration. (A) MIP-1 $\beta 4 \mathrm{~h}$ after injection. Human $\mathrm{CD}^{+} \mathrm{T}$ cells (arrow) at peritoneal surface $(25 \times)$. $(B)$ MIP-1 $\beta 4 \mathrm{~h}$ after injection. $\mathrm{CD}^{+} \mathrm{T}$ cells $(a r-$ row) at peritoneal surface $(66 \times)$. (C) IL- $872 \mathrm{~h}$ after injection. $\mathrm{CD}^{+}$ $\mathrm{T}$ cells (arrow) at peritoneal surface and in deep muscle $(25 \times) .(D)$ rhIL-8 $72 \mathrm{~h}$ after injection. $\mathrm{CD}^{+} \mathrm{T}$ cells (arrow) in deep muscle $(66 \times)$. (E) Immunohistology of 8C5-treated mice with rhIL-8 $72 \mathrm{~h}$ after injection. No human $\mathrm{CD}^{+}$cells present $(33 \times)$.

(HRP) (Sigma Chemical Co.) was the enzyme standard and the results were expressed as $\mu \mathrm{g}$ equivalents of HRP per milliliter.

In all experiments, a DynaTech spectrophotometer was used in the analysis of enzymatic activity. Protein levels of granule fractions were determined by ultraviolet absorption at $210 \mathrm{~nm}$.

\section{Results}

rhIL-8 induces significant murine neutrophil but little human $T$ cell infiltration after $4 \mathrm{~h}$ in huPBL-SCID mice. Previous studies from several laboratories have shown IL-8 to be a potent neutrophil and lymphocyte chemoattractant both in vivo and in vitro (20-23). However, the direct effects of IL-8 on human T cell migration still remain controversial using standard in vitro chemotaxis assays (24). We therefore wanted to evaluate rhIL-8 on human $\mathrm{T}$ cell infiltration in vivo utilizing a human/ mouse migration system we have recently described $(37,38)$. HuPBL were initially transferred intraperitoneally into SCID mice. The mice were then injected subcutaneously with either $1 \mu \mathrm{g}$ of rhIL-8, MIP-1 $\beta$, or HBSS once daily. 4 or $72 \mathrm{~h}$ after the initial cell transfer, the injection site and underlying tissue were biopsied and examined by immunohistology for the presence of human $\mathrm{CD}^{+} \mathrm{T}$ cells. Four hours after injection, rhIL-8 induced significant murine neutrophil infiltration into the injection area as determined by histology (Fig. 1, $B$ and $C$ ). These results are consistent with previous reports describing the inflammatory properties of IL-8 (4-6). Few or no mononuclear cells were also observed at this time point but immuno- 
Table I. Effect of rhIL-8 and rhMIP-1 $\beta$ on Human T Cell Infiltration in huPBL-SCID Mice

\begin{tabular}{|c|c|c|c|}
\hline Exp. & Time point* & Treatment & $\begin{array}{l}\text { Extent of } \mathrm{CD}^{\text {+ }}{ }^{+} \\
\text {infiltration }^{\ddagger}\end{array}$ \\
\hline \multirow[t]{9}{*}{1} & $4 \mathrm{~h}$ & - & - \\
\hline & & - & - \\
\hline & & rhMIP-1 $\beta$ & $2+$ \\
\hline & & rhMIP-1 $\beta$ & $2+$ \\
\hline & & rhMIP-1 $\beta$ & - \\
\hline & $72 \mathrm{~h}$ & - & - \\
\hline & & - & - \\
\hline & & rhMIP-1 $\beta$ & $2+$ \\
\hline & & rhMIP-1 $\beta$ & - \\
\hline \multirow[t]{13}{*}{2} & $4 \mathrm{~h}$ & - & - \\
\hline & & - & - \\
\hline & & - & - \\
\hline & & - & - \\
\hline & & - & - \\
\hline & & rhIL-8 & - \\
\hline & & rhIL-8 & - \\
\hline & & rhIL-8 & - \\
\hline & & rhIL-8 & $1+$ \\
\hline & & rhIL-8 & - \\
\hline & $72 \mathrm{~h}$ & rhIL-8 & $1+$ \\
\hline & & rhIL-8 & $2+$ \\
\hline & & rhIL-8 & $2+$ \\
\hline \multirow[t]{6}{*}{3} & $72 \mathrm{~h}$ & - & - \\
\hline & & - & - \\
\hline & & rhMIP-1 $\beta$ & - \\
\hline & & rhMIP-1 $\beta$ & $1+$ \\
\hline & & rhIL-8 & $1+$ \\
\hline & & rhIL-8 & $3+$ \\
\hline \multirow[t]{7}{*}{4} & $72 \mathrm{~h}$ & - & - \\
\hline & & rhMIP-1 $\beta$ & - \\
\hline & & rhMIP-1 $\beta$ & - \\
\hline & & rhMIP-1 $\beta$ & $2+$ \\
\hline & & rhIL-8 & - \\
\hline & & rhIL-8 & $1+$ \\
\hline & & rhIL-8 & $2+$ \\
\hline
\end{tabular}

*Immunohistology performed on tissue biopsy sections at 4 or $72 \mathrm{~h}$ after huPBL injection (each experiment represents a different huPBL donor) using a MoAb to human CD3 as described in Methods. ${ }^{\ddagger}$ Injection sites were examined microscopically without knowledge of experimental treatment. Immunostaining was graded from minimal (1+) to extensive $(4+)$ based on the intensity and distribution of $\mathrm{CD}^{+} \mathrm{T}$ cells.

histological examination failed to reveal significant human $\mathrm{T}$ cell infiltration (Table I). In contrast, rhMIP- $1 \beta$ induced predominantly mononuclear cell infiltrates at this $4 \mathrm{~h}$ time point. Immunohistological analysis revealed that the majority of the cells found within this MIP- $1 \beta$-induced infiltrate were $\mathrm{CD}^{+}$ human T cells (Fig. 2, $A$ and $B$, Table I). Thus, treatment of huPBL-SCID mice with rhIL-8 induced significant murine neutrophil but little human $\mathrm{T}$ cell migration within $4 \mathrm{~h}$, while rhMIP-1 $\beta$ induced predominantly human $\mathrm{T}$ cell and murine monocyte migration at this same time interval. This rapid
MIP-1 $\beta$-induced human T cell infiltration supports a direct effect on T cells and supports our previous findings that MIP- $1 \beta$ is a potent $\mathrm{T}$ cell chemoattractant (23).

rhIL-8 induces significant human T cell migration after $72 h$ in huPBL-SCID mice and the infiltration is dependent on murine neutrophils. Upon examination of huPBL-SCID mice $72 \mathrm{~h}$ after chemokine injection, markedly different cell types were detected infiltrating the biopsy site. Mice treated with rhIL-8 demonstrated significant mononuclear cell infiltration at this time point with evidence of continued murine neutrophil infiltration (Fig. 1, $D$ and $E$, Table I). The vast majority of these mononuclear cells were found to be human $\mathrm{CD}^{+} \mathrm{T}$ cells (Fig. $2 \mathrm{C}$ ). Both $\mathrm{CD}^{+}$and $\mathrm{CD} 8^{+} \mathrm{T}$ cells were found to be present in comparable amounts (data not shown). The mice injected with MIP-1 $\beta$ for $72 \mathrm{~h}$ exhibited similar levels of human T cells infiltration to that observed at the 4-h time point (Table I). Interestingly, the extent of the human $\mathrm{T}$ cell infiltration in response to IL-8 after $72 \mathrm{~h}$ was greater than that observed with other chemokines such as RANTES (37) and MCP-1 (38) or MIP$1 \beta$, which directly induce human $\mathrm{T}$ cell migration in vitro (23). Thus, rhIL-8 is capable of inducing significant human T cell infiltration in vivo at $72 \mathrm{~h}$ when compared with other chemokines such as MIP-1ß. This lymphocyte migration appears to occur after an induction of murine neutrophil infiltration in the injection site. These results suggested that human $\mathrm{T}$ cell infiltration in response to rhIL-8 may be indirect in this huPBLSCID mouse model through the release of substances by murine neutrophils upon entry into the injection sites.

In an effort to determine whether human $T$ cell infiltration into IL-8 injections sites was due to prior neutrophil entry, we injected mice with the neutrophil depleting antibody, $8 \mathrm{C} 5$, and histologically examined IL-8 injection sites after 4 and $72 \mathrm{~h}$ for neutrophil and $\mathrm{T}$ cell infiltration. The results in Fig. 3 demonstrate that IL- 8 injection sites in 8C5-treated mice failed to exhibit any leukocyte infiltration at 4 and $72 \mathrm{~h}$ while control mice demonstrated a profound neutrophil and lymphocyte infiltration at these time intervals after IL-8 administration. Immunohistology demonstrated that no human $\mathrm{T}$ cells were present in the IL-8 injection sites in 8C5-treated mice after $72 \mathrm{~h}$ (Fig. 2 $E$ ). These results suggest that neutrophil infiltration may be an important prerequisite for subsequent $\mathrm{T}$ cell migration into inflammatory areas.

IL-8 and FMLP induce the release of azurophilic and specific granule contents from human neutrophils bound to fibronectin. Since neutrophils appear to contribute to human $\mathrm{T}$ cell migration observed in vivo, the capacity of IL-8 to stimulate the production or release of $\mathrm{T}$ cell chemoattractants from human neutrophils was then investigated. Human neutrophils were stimulated with either IL-8 (50 ng/ml), A23187 (500 nM), or medium alone for $4 \mathrm{~h}$ at $37^{\circ} \mathrm{C}$ on fibronectin- or uncoated tissue culture plates, after which supernatants were collected and tested for enzyme release and chemotactic activity. The results in Table II demonstrate that IL- 8 induced the release of lactoferrin, $\beta$-glucuronidase, and myeloperoxidase from neutrophils on fibronectin- but not non-coated plates. The low LDH levels observed in all the neutrophil cultures suggest that the release of the various enzymes is not due to cell death. The calcium ionophore A23187 was used as positive control and, contrary to previous findings, induced both azurophilic and specific granule release on both fibronectin- and noncoated plates $(32,39)$. Similar degranulation results were observed using FMLP and PMA (data not shown). It is indeed interesting 

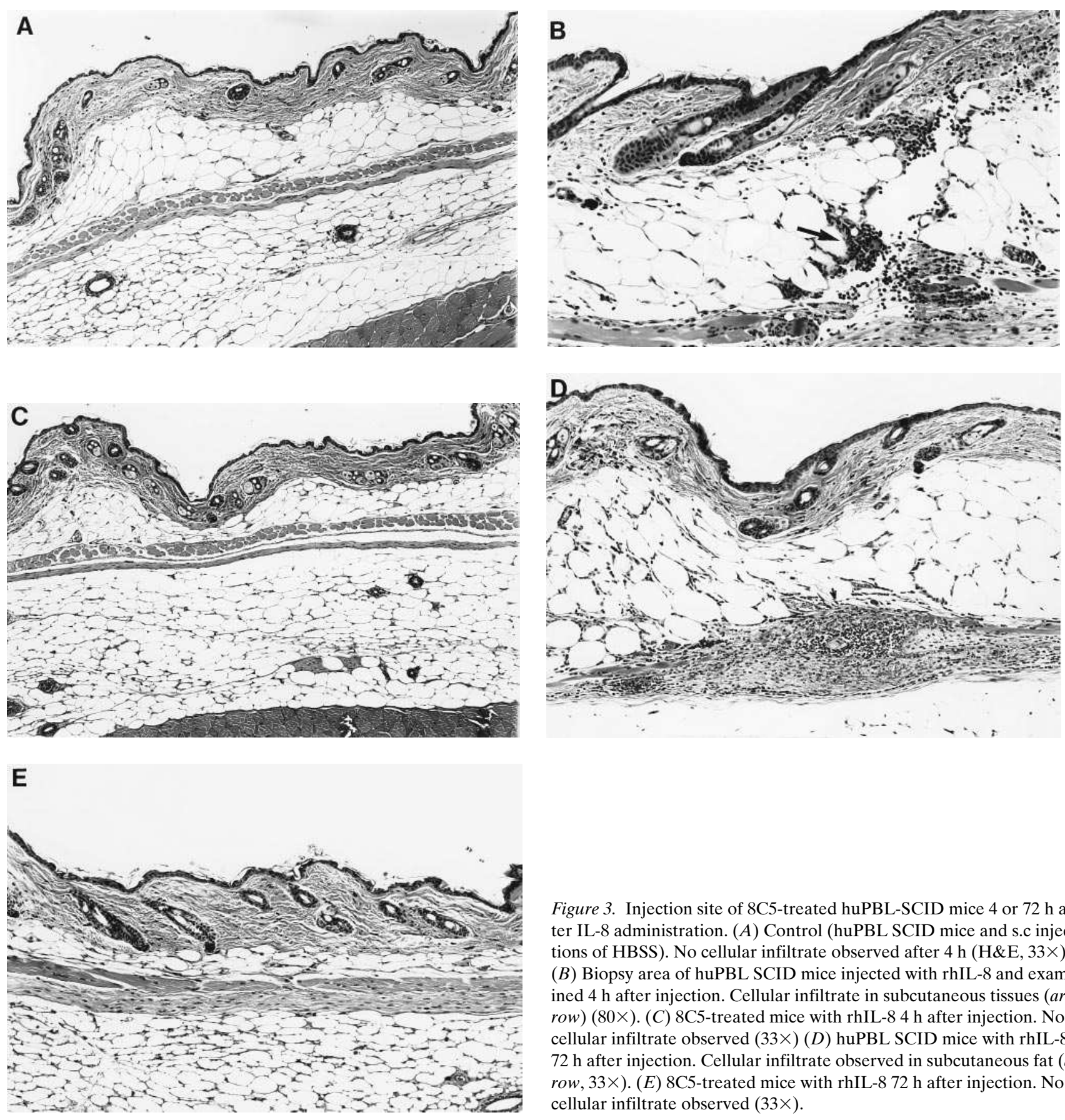

Figure 3. Injection site of 8C5-treated huPBL-SCID mice 4 or $72 \mathrm{~h}$ after IL-8 administration. $(A)$ Control (huPBL SCID mice and s.c injections of HBSS). No cellular infiltrate observed after $4 \mathrm{~h}(\mathrm{H} \& \mathrm{E}, 33 \times)$. $(B)$ Biopsy area of huPBL SCID mice injected with rhIL-8 and examined $4 \mathrm{~h}$ after injection. Cellular infiltrate in subcutaneous tissues ( $\mathrm{ar}$ row) $(80 \times)$. (C) 8 C5-treated mice with rhIL-8 $4 \mathrm{~h}$ after injection. No cellular infiltrate observed $(33 \times)(D)$ huPBL SCID mice with rhIL-8 $72 \mathrm{~h}$ after injection. Cellular infiltrate observed in subcutaneous fat (arrow, 33×). (E) 8C5-treated mice with rhIL-8 $72 \mathrm{~h}$ after injection. No cellular infiltrate observed $(33 \times)$.

that IL-8 and FMLP (data not shown) also permitted the release of both azurophilic and specific granule products in the presence of fibronectin. Previous studies have demonstrated that only specific granules (in the absence of cytochalasin B) release their contents in response to IL-8 and FMLP $(18,19$, 32). IL-8-induced neutrophil degranulation appears to require the presence of active VLA molecules, because neutralization analysis with monoclonal antibodies specific for CD29 but not for CD18 or VLA-6 inhibited neutrophil degranulation (data not shown). In certain neutrophil preparations, IL-8-induced degranulation was also found to be enhanced on VCAM-1coated plates; however, this VCAM-1 effect appeared to be due to the presence of contaminating eosinophils.

Supernatants derived from IL-8- or FMLP-stimulated

PMNs induce leukocyte chemotaxis. Neutrophil-derived supernatants were also tested for their ability to chemoattract leukocytes. Fig. 4 demonstrates that IL-8, FMLP, and PMA each induces the release of chemotactic mediator(s) from human neutrophils with potent chemotactic effects on monocytes and $\mathrm{T}$ cells. These neutrophil-derived chemotactic factor (NDCF) preparations induced a dose-dependent in vitro chemotaxis of all these cell types with typical bell-shaped curves (Fig. $4 \mathrm{~B}$ ). The chemokine RANTES was used as a positive control in these studies and similarly induced potent $\mathrm{T}$ cell migration (data not shown).

While these studies suggest that IL-8, FMLP, and PMA can induce neutrophil degranulation and the release or production of chemotactic factor(s), the presence of these stimulatory 
agents (IL-8, FMLP, and PMA) in the NDCF preparations makes if difficult to determine whether the granule products alone are responsible for cell migration or whether this migration is influenced or occurs in response to these stimulators. Thus, unstimulated human and mouse neutrophil granule preparations (as described in Methods) were tested for their ability to induce leukocyte migration. Through a series of sucrose and percoll gradient fractionations of our neutrophil preparations, we have isolated whole (nonlysed) PMN granules which contain all the known enzymes of neutrophils (both specific and azurophilic granules). Fig. $5 \mathrm{~A}$ demonstrates that granules of unstimulated human neutrophils (NGs) contain very potent chemoattractants for monocytes and $\mathrm{T}$ cells. As with the NDCF preparations, NGs induced a dose-dependent chemotactic response of all the tested cell types. Similarly, enriched mouse NGs also promoted human $\mathrm{T}$ cell and monocyte migration in vitro (Fig. $5 \mathrm{~B}$ ). The studies using the mouse NG
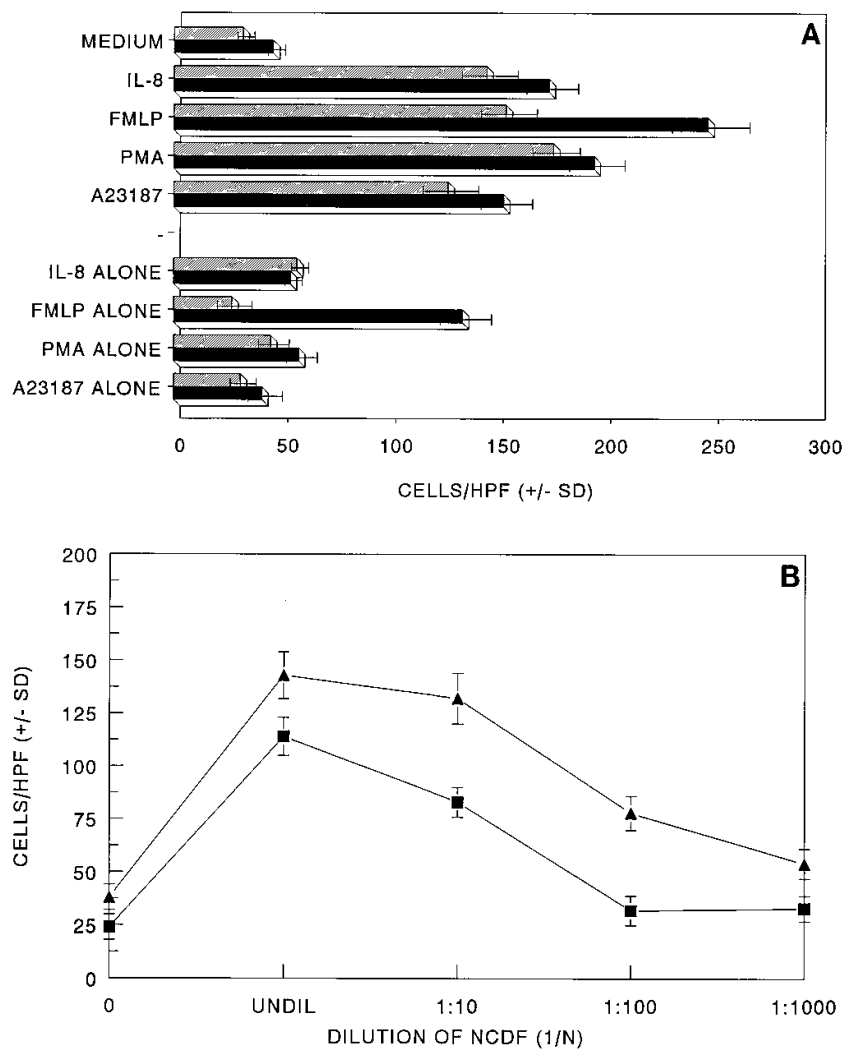

Figure 4. Supernatants derived from IL-8- and FMLP-stimulated neutrophils are chemotactic for T cells and monocytes. Human neutrophils were either cultured alone on fibronectin-coated plates or in the presence of IL-8 $(50 \mathrm{ng} / \mathrm{ml})$, FMLP $\left(10^{-7} \mathrm{M}\right)$, PMA $(2 \mathrm{ng} / \mathrm{ml})$, or A23187 $(500 \mathrm{nM})$ for $4 \mathrm{~h}$ at $37^{\circ} \mathrm{C}$ after which supernatants were collected. Medium containing IL-8, FMLP, PMA, and A23187 alone were also tested for their ability to facilitate chemotaxis as controls. Various dilutions of these neutrophil-derived supernatants were placed in the lower wells of a microchemotaxis chamber and subsequently tested for their ability to induce leukocyte chemotaxis. Purified human T cells ( $A$, shaded bar; $B$, closed square) or monocytes $(A$, solid bar; $B$, closed triangle) were placed in the upper well of the chamber and incubated for various time periods at $37^{\circ} \mathrm{C}$. The results are expressed as the mean number of migrating leukocytes per high power field $( \pm \mathrm{SD})$. Similar results have been observed using at least six different $\mathrm{T}$ cell and neutrophil donors $(n=6)$. preparations are quite important as our in vivo studies would suggest that the influx of mouse neutrophils would preface human $\mathrm{T}$ cell infiltration in the presence of IL-8. The fact that mouse NGs operate on human T cells and monocytes strongly supports our hypothesis.

It was important to distinguish directed movement (chemotaxis) through the filters of a Boyden chamber as opposed to merely accelerated random movement (chemokinesis). The checkerboard analysis in Table III demonstrates that NGs are both chemotactic and chemokinetic for $\mathrm{T}$ cells as well as monocytes. Depending on the NG donor, 35-50\% of the mi-
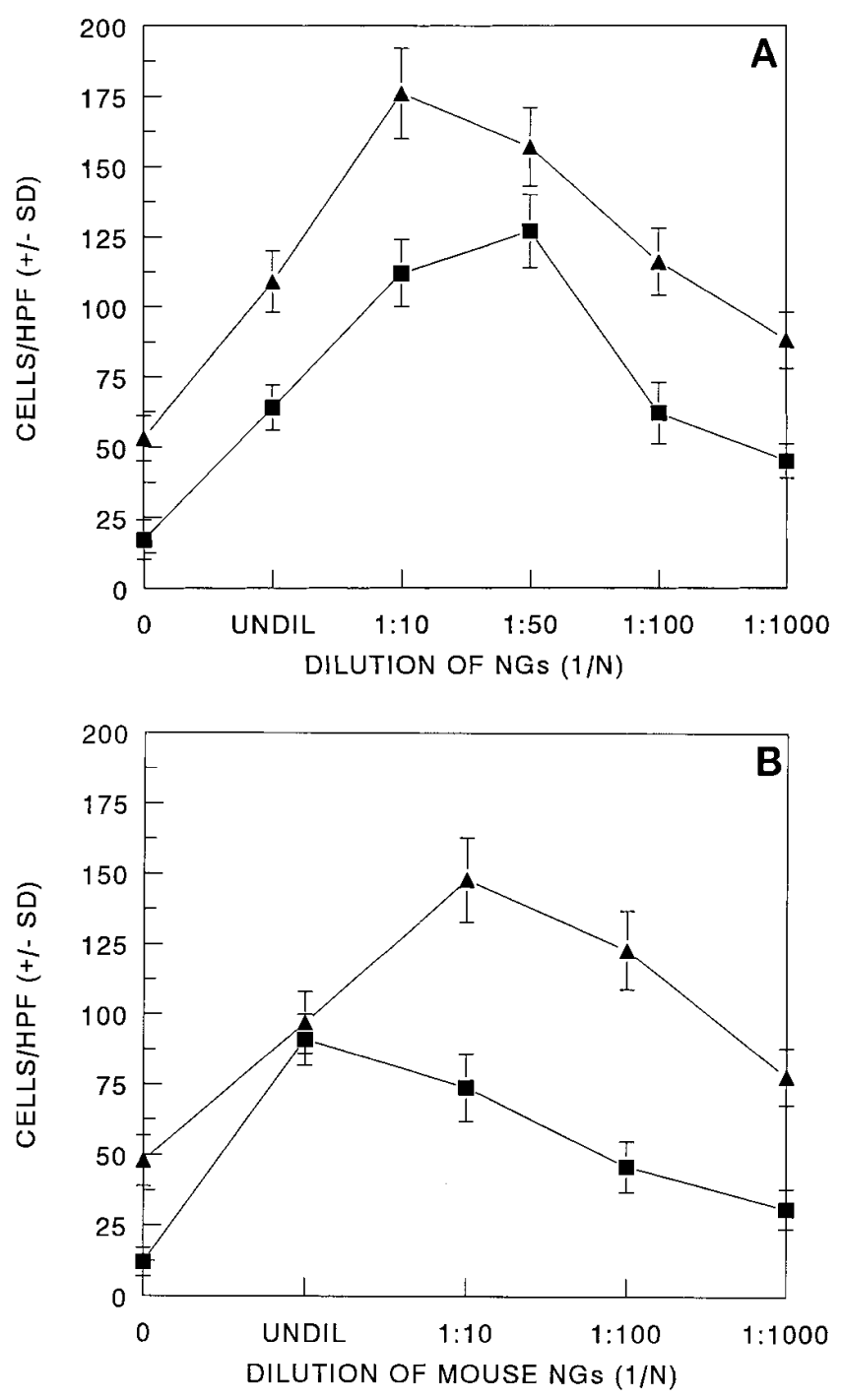

Figure 5. Purified neutrophil granules (NGs) are chemotactic for T cells and monocytes. Enzyme-active fractions of the neutrophil granule preparations were pooled and tested for their ability to induce leukocyte migration (as described in Methods). Various dilutions of the pooled preparations were placed in the lower wells of a microchemotaxis chamber and subsequently tested for their ability to induce leukocyte chemotaxis. Purified T cells $(\boldsymbol{\square})$ or monocytes $(\boldsymbol{\Delta})$ were placed in the upper well of the chamber and incubated for various time periods at $37^{\circ} \mathrm{C}$. The results are expressed as the mean number of migrating leukocytes per high power field $( \pm S D)$. Similar results have been observed using several $\mathrm{T}$ cell and neutrophil donors $(n=5)$. 
gration observed in response to NGs was chemokinetic as opposed to chemotactic suggesting that multiple mediators may be present within NGs preparations. Similar results were observed with the NDCF preparations (data not shown).

Fig. $6 \mathrm{~A}$ demonstrates that NGs contain chemoattractants for both $\mathrm{CD}^{+}$and $\mathrm{CD}^{+} \mathrm{T}$ cell subsets. $\mathrm{CD} 4^{+} \mathrm{T}$ cells appeared to be significantly more responsive to the NG preparations than $\mathrm{CD}^{+} \mathrm{T}$ cells. The cloned $\mathrm{CD}^{+}$tetanus-toxoid reactive human $\mathrm{T}$ cell clone, 3E12, also migrated in response to NGs (Fig. 6 B).

Neutralization analysis reveals that the majority of the NG activity is not due to chemokines. To determine whether any of the chemotactic activity within NGs is due to the presence of chemokines, the effects of neutralization using specific antibodies against MIP- $1 \alpha$, MIP- $1 \beta$, RANTES, MCP-1, and IL- 8 was tested. Fig. 7 demonstrates that only $\sim 15-18 \%$ of the chemotactic activity for T cells in NGs was neutralized by the addition of anti-MIP- $1 \alpha$ and anti-MIP-1 $\beta$ antibody and $<10 \%$ was neutralized by the addition of anti-IL- 8 antibody.
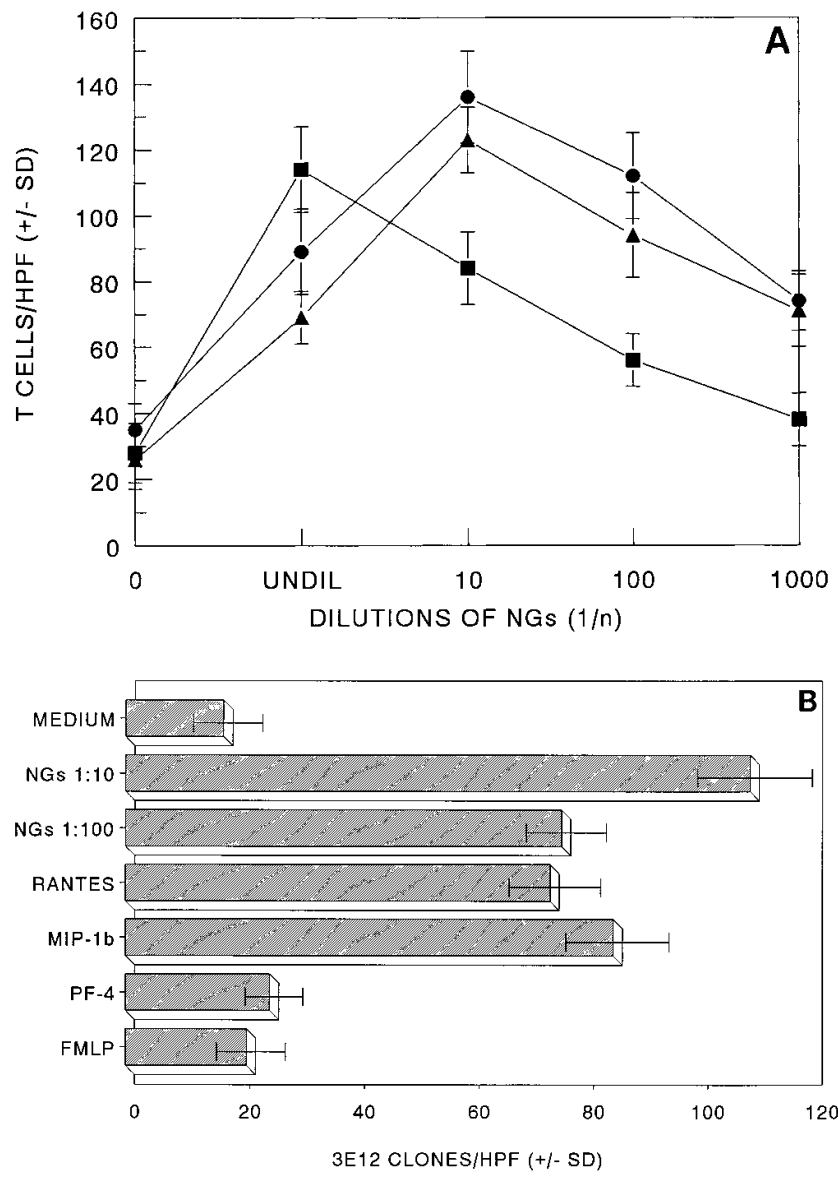

Figure 6. Both $\mathrm{CD}^{+}$and $\mathrm{CD} 8^{+} \mathrm{T}$ cells and $\mathrm{T}$ cell clones migrate in response to NG preparations. ( $A$ ) Purified human $\mathrm{CD}^{+}(\mathbf{\Lambda}), \mathrm{CD}^{+}$ $(\square)$, or unfractionated human $\mathrm{T}$ cells $(\bullet)$ were tested for their ability to migrate in response to various dilutions of NGs. $(B)$ The human $\mathrm{CD}^{+}$tetanus-toxoid-reactive $\mathrm{T}$ cell clone, $3 \mathrm{E} 12$, was also tested for its ability to migrate in response to NGs, RANTES $(0.1 \mathrm{ng} / \mathrm{ml})$, MIP$1 \beta(1 \mathrm{ng} / \mathrm{ml})$, IL-8 $(10 \mathrm{ng} / \mathrm{ml})$, or FMLP $\left(10^{-7} \mathrm{M}\right)$. The results are expressed as the mean number of migrating $T$ cells per high power field $( \pm \mathrm{SD})$. These studies have been performed at least three times with similar results $(n=3)$.

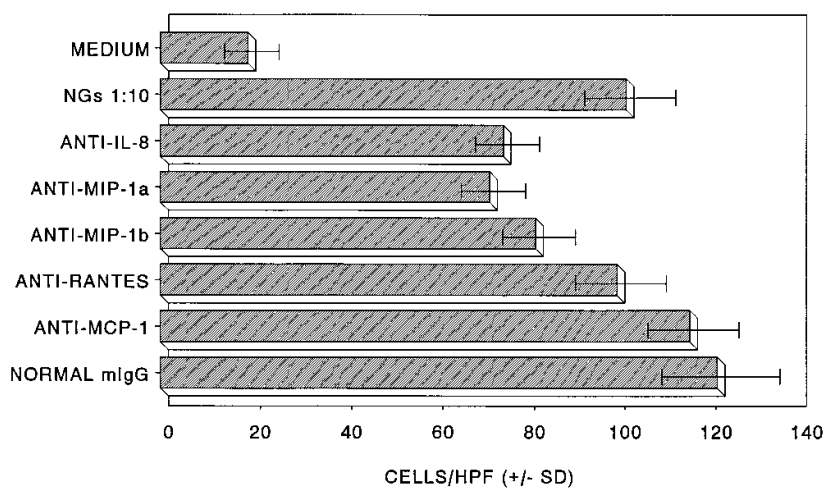

Figure 7. Neutralization analysis reveals that the majority of the NGinduced $\mathrm{T}$ cell migration is not due to chemokines. NG preparations or control chemokines were incubated in the presence or absence of neutralizing antibodies to the chemokines MIP- $1 \alpha$, MIP- $1 \beta$,

RANTES, MCP-1, and IL-8 (used at $20 \mu \mathrm{g} / \mathrm{ml}$ ) or control mouse $\mathrm{IgG}$ (used at $20 \mu \mathrm{g} / \mathrm{ml}$ ). After $1 \mathrm{~h}$ at $37^{\circ} \mathrm{C}$, NG and control preparations were tested for chemotactic activity in a microchemotaxis chamber. The results are expressed as the mean number of migrating $\mathrm{T}$ cells per high power field $( \pm \mathrm{SD})$. While not shown, control mouse Ig also failed to reduce the T cell chemotactic activity of NGs and each of the anti-chemokine antibodies specifically neutralized their specific ligand counterparts.

However, no significant inhibition was observed by the addition of anti-RANTES, or -MCP-1 antibody to the chemotaxis assays. These antibodies were found to completely neutralize the activity of their specific recombinant chemokines in vitro (data not shown). These results suggest the possibility that low concentrations of the chemokines MIP- $1 \alpha$, MIP-1 $\beta$, and IL- 8 are present within NG preparations but that most of the chemoattractant activity is due to other chemoattractants.

Azurophilic and specific granule products induce T cell migration in vitro. In an effort to determine whether the chemotactic products derived from NGs are localized in either the azurophilic or specific granule compartments, sucrose gradients were utilized to separate the various granule fractions. Granule fractions were tested for the presence of lactoferrin, $\beta$-glucuronidase, $\mathrm{LDH}$, and myeloperoxidase to differentiate fractions containing azurophilic vs specific granule contents and were subsequently examined for $\mathrm{T}$ cell and monocyte chemotactic activity. As previously described by West et al. (30-32), fractions 1 and 2 contain the majority of the $\beta$-glucuronidase and myeloperoxidase activity, while fraction 3 contains most of the lactoferrin activity (data not shown). The results in Fig. 8 demonstrate that both enriched azurophilic and specific granules yielded $\mathrm{T}$ cell and monocyte chemotactic factors. The chemotactic potency of these fractions was much less compared to the unfractionated NG control. However, this may be due to loss of activity in the course of fractionation of these granules over a sucrose gradient. Alternatively, factors from each granule type may act additively or synergistically when administered together. These results suggest that both azurophilic and specific granules contain $\mathrm{T}$ cell and monocyte chemoattractants.

\section{Discussion}

The accumulation of monocytes and lymphocytes at sites of inflammation is generally preceded by an initial influx of neutro- 


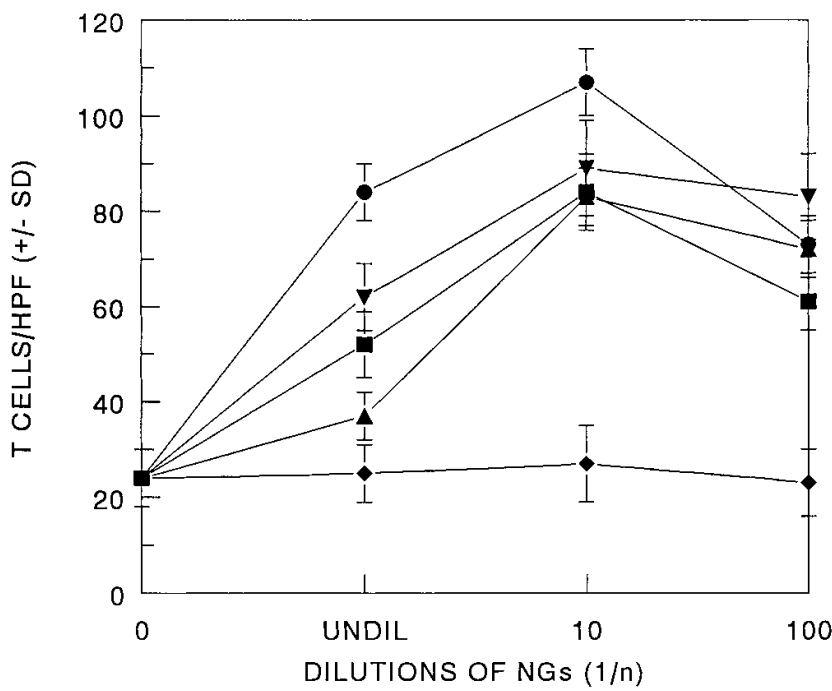

Figure 8. Both azurophilic and specific granule products induce $\mathrm{T}$ cell migration in vitro. Using sucrose gradients, NGs were separated into various granule fractions and tested for the presence of various enzymes present in both azurophilic or specific granules. Enzyme-active fractions were then tested for their ability to induce $\mathrm{T}$ cells migration using the procedures described in Figs. 6-8. The results in panel $b$ are expressed as the mean number of migrating $T$ cells per high power field $( \pm \mathrm{SD})$. These studies have been performed at least three times using different donor $\mathrm{T}$ cells and granule preparations with similar results $(n=3)$. ( $)$ NGs; $(\mathbf{\Delta})$ fraction $1 ;(\boldsymbol{\square})$ fraction 2; ( $)$ fraction 3; $(\diamond)$ buffer.

phils. A number of agents have been shown to activate neutrophils and to induce neutrophil infiltration into inflammatory sites, including FMLP, the anaphylotoxin C5a, and IL-8. IL-8 has been shown to induce neutrophil adhesion to inflamed endothelial cells, neutrophil migration, superoxide release, and degranulation (4-6). Besides the effects of IL-8 on PMN functions, it has also been shown to be a T cell chemoattractant (4-6, 20-24). Only some laboratories have been able to reproduce these findings and the effect of IL-8 on T-cell recruitment is still controversial. In the present report, we have demonstrated that IL-8 is indeed a potent T cell migratory agent in vivo. The chimeric hu/SCID mice exhibited marked $\mathrm{T}$ cell infiltration by $72 \mathrm{~h}$. This occurred despite the fact that a human cytokine was used to attract human $\mathrm{T}$ lymphocytes in a murine milieu necessitating the interaction of migrating human $\mathrm{T}$ cells with murine adhesion proteins and cells. However, this chemotactic effect appears to be delayed and murine neutrophil-dependent.

The delayed $T$ cell migratory response to IL- 8 may simply be due to a requirement for a higher chemokine dose or gradient in vivo. When only one injection of rhIL- 8 was administered and the skin was biopsied $72 \mathrm{~h}$ later, human $\mathrm{T}$ cells were also detected at the injection site although not to the same extent as with three injections (data not shown). We are currently examining murine neutrophils to determine if their products work on human $\mathrm{T}$ cells in vitro. The in vivo data do demonstrate the ability of the huPBL-SCID model to detect cellular interactions that may exert potent physiological responses.

Neutrophils and their secretory products participate in the host response to a number of infectious and noninfectious disease states as well as in facilitating leukocyte migration (41-
45). Many of the neutrophil's biologically active components are contained within its granules and are released into the extracellular space in response to appropriate stimuli. Human neutrophils contain thousands of these cytoplasmic granules. These membrane-bound organelles function as storage compartments for macromolecules destined for secretion (stored in "specific" or "secondary" granules) or for fusion with phagosomes ("azurophilic" or "primary" granules) (46-50). The azurophilic granules contain a diverse array of enzymes, including cathepsins A,D,E, 5'-nucleotidase, $\beta$-galactosidase, arylsulfatase, $\alpha$-mannosidase, $N$-acetyl- $\beta$-glucosaminidase, $\beta$-glucuronidase, acid $\beta$ glycerophosphatase, cathepsin $G$, elastase, collagenase, myeloperoxidase, muraminidase, cationic peptides, azurocidin and the defensins HNP-1, HNP-2, and HNP-3 whilst the specific granules contain lactoferrin, alkaline phosphatase, lysozyme, vitamin- $\mathrm{B}_{12}$-binding protein, neutral proteases, and probably collagenase. In general, the release of specific granule enzymes into the medium is high in comparison with azurophilic granule enzymes. Because specific granules fuse more rapidly with phagosomes than do azurophilic granules, they would more likely be involved if granule release occurred into a developing phagosome before it had been closed to the exterior. Although most of the stimuli that produce granule enzyme release affect both granule types more or less equally, there are stimuli with considerable selectivity for specific granules (51-56). These include PMA, ionomycin, concanavalin A, C5a, NaF, lithium, serum-activated zymosan particles FMLP, and the $\alpha$ chemokine IL-8. The present data support the concept that IL-8 and FMLP are potent degranulating and chemotactic agents for human polymorphonuclear neutrophils; however, we have only observed enzyme release in response to IL-8 in the presence of certain adhesion ligands such as fibronectin. VCAM-1-coated plates were also found to promote neutrophil degranulation; however, in all of these cases, contaminating eosinophils were observed in these PMN preparations (data not shown). As eosinophils but not neutrophils bear VLA-4 integrin molecules on their cell surface, we believe that low level eosinophil contamination of PMN preparations may have influenced neutrophil degranulation in the presence of VCAM-1. These results suggest that neutrophil adhesion in conjunction with IL-8 or FMLP provide the necessary signals to promote the degranulation and chemotactic processes.

A recent study depleting neutrophils from rat by treatment with anti-rat neutrophil antiserum is reported to have reduced subsequent development of chronic delayed-type hypersensitivity reactions (57-58). This supports the concept that a factor(s) derived from the neutrophils may be important for subsequent monocyte and lymphocyte mobilization. Neutrophils are believed to regulate the accumulation of inflammatory cell populations by producing a number of low MW chemotactic factors such as leukotriene $\mathrm{B}_{4}\left(\mathrm{LBT}_{4}\right)$, which can attract more neutrophils and monocytes into the inflammatory sites (59). However, we believe that neutrophils also regulate T-lymphocyte accumulation in inflammatory sites by the production and storage of T cell chemoattractants.

For neutrophil granules to yield $\mathrm{T}$ cell chemotactic factors in vivo, the chemoattractant would need to be released either as a result of degranulation or cell death. In this respect, we have demonstrated that NGs are released into the extracellular milieu when neutrophils are stimulated with IL-8. Almost $40 \%$ of the total NGs were released extracellularly after $4-6 \mathrm{~h}$ 
Table II. IL-8-induced Release of Granule Contents from Human Neutrophils Bound to Fibronectin*

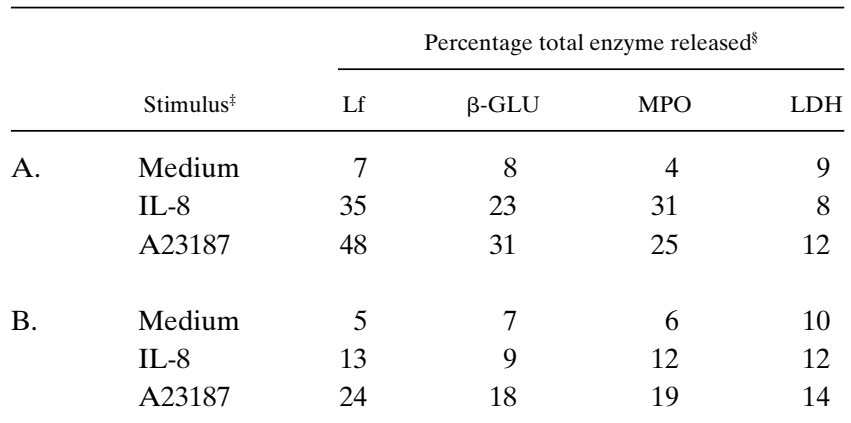

* Purified human neutrophils from a representative donor were incubated on either $(A)$ fibronectin- or $(B)$ noncoated plates for $30 \mathrm{~min}$ at $37^{\circ} \mathrm{C}$ before the addition of the stimulus. ${ }^{*} \mathrm{IL}-8(50 \mathrm{ng} / \mathrm{ml})$ or A23187 $(500 \mathrm{nM})$ were incubated for $4 \mathrm{~h}$ at $37^{\circ} \mathrm{C}$ in a serum-free medium. ${ }^{\S}$ Supernatants and cell pellets were then collected and assessed for their enzyme content compared to control nontreated cultures. The results are expressed as the percentage of total enzyme in unstimulated neutrophils at time $0( \pm$ SEM $)$. Similar results have been observed using several neutrophil donors $(n=5)$. $L f$, lactoferrin; $\beta$-GLU, $\beta$-glucuronidase; $M P O$, myeloperoxidase; $L D H$, lactate dehydrogenase.

of IL-8 exposure. Similarly, FMLP and PMA induced NG release by $6 \mathrm{~h}$ with $>60 \%$ granule release (Table II).

Chemokine receptors have long been known to be coupled with G-proteins sensitive to bacterial toxins (40). In the current manuscript, pertussis toxin failed to block the majority of the NG-induced $\mathrm{T}$ cell and monocyte chemotaxis as only a small percentage $(\leq 15 \%)$ of the NG chemotactic activity was found to be inhibited (data not shown). These results suggest that factors like chemokines that interact with G-protein linked receptor are not the predominant factors in our NDCF preparations. This is supported by the neutralization studies in Fig. 7. In addition, the use of cycloheximide, cyclophosphamide, and actinomycin $\mathrm{D}$ with the neutrophil preparations revealed that active transcription and translation does not appear to be necessary for NDCF activity. However, we can not

Table III. Checkerboard Analysis of NG-induced Migratory Activity

\begin{tabular}{lcccr}
\hline & \multicolumn{4}{c}{ Dilution in upper wells $( \pm$ SD) } \\
\cline { 2 - 5 } $\begin{array}{l}\text { Dilution NG in } \\
\text { lower wells }\end{array}$ & 0 & $1: 10$ & $1: 50$ & $1: 100$ \\
\hline 0 & $19(5)$ & $51(5)$ & $78(8)$ & $37(9)$ \\
$1: 10$ & $86(9)$ & $53(7)$ & $65(6)$ & $100(11)$ \\
$1: 50$ & $167(17)$ & $74(9)$ & $89(10)$ & $114(13)$ \\
$1: 100$ & $79(6)$ & $52(4)$ & $74(9)$ & $94(11)$ \\
& & & &
\end{tabular}

* Different dilutions of NGs were placed in the upper and/or lower wells of the chemotaxis chamber. A fibronectin-coated polycarbonate filter separated from the fresh purified $\mathrm{T}$ cells was placed in the upper wells from the NG dilutions in the lower wells. The chemotaxis chamber was incubated at $38^{\circ} \mathrm{C}$ for $4 \mathrm{~h}$ in $5 \% \mathrm{CO}_{2}$. After incubation, the filter was removed, scraped, fixed in methanol, stained, and counted on a light microscope or an image analyzer. ${ }^{\ddagger}$ The results are expressed as the number of migrating $\mathrm{T}$ cells per high power field $( \pm \mathrm{SD})$. This experiment has been performed several times with similar results $(n=3)$. exclude the ability of these blocking agents to inhibit the production of some chemotactic factors by the neutrophils (data not shown).

At the initiation of an inflammatory response, a number of cytokines are released including IL- 1 and TNF $\alpha$. Cytokineactivated keratinocytes, tissue macrophages, melanocytes, smooth muscle cells, and endothelial cells are induced by IL-1, TNF $\alpha$, and other stimuli to produce IL-8. PMNs attracted to the sites of IL- 8 production are then induced to degranulate, releasing their intracellular granule contents into the extracellular milieu. Chemoattractants released from NGs at the site of inflammation are able to specifically attract $\mathrm{T}$ lymphocytes to the site of NG release. While there are a number of chemotactic proteins produced at sites of chronic inflammation, this neutrophil-mediated migratory event occurs early in the initiation of immune inflammation. The release of NGs participates in a cascade of activating events and serves to bring mononuclear cells to inflammatory sites. The identity of some NDCFs has been established to be the defensins, HNP-1 and HNP-2, and CAP37 (Chertov, O., D.F. Michiel, L. Xu, J.M. Wang, W.J. Murphy, D.L. Longo, D.D. Taub, and J.J. Oppenheim, J. Biol. Chem. In press.), but the relative contribution of these chemotactic factors to the evolution of inflammatory responses remains to be established.

\section{Acknowledgments}

We would like to thank Shirley Hale, Kelli Taylor, Barbara Kasprzak, Mike Key, and Susan Corrales for their excellent technical support in performing many of these studies.

\section{References}

1. Walz, A., P. Peveri, H. Aschauer, and M. Baggiolini. 1987. Purification and amino acid sequencing of NAF, a novel neutrophil-activating factor produced by monocytes. Biochem. Biophys Res. Commun. 149:755-761.

2. Yoshimura, T., K. Matsushima, S. Tanaka, E.A. Robinson, E. Appella, J.J. Oppenheim, and E.J. Leonard. 1987. Purification of a human monocytederived neutrophil chemotactic factor that has peptide sequence similarity to other host defense cytokines. Proc. Natl. Acad. Sci. USA. 84:9233-9237.

3. Matsushima, K., K. Morishita, T. Yoshimura, S. Lavu, Y. Kobayashi, W. Lew, E. Appella, H.F. Kung, E.J. Leonard, and J.J. Oppenheim. 1988. Molecular cloning of a human monocyte-derived neutrophil chemotactic factor (MDNCF) and the induction of MDNCF mRNA by interleukin 1 and tumor necrosis factor. J. Exp. Med. 167:1883-1893.

4. Oppenheim, J.J., C.O.C. Zachariae, N. Mukaida, and K. Matsushima. 1991. Properties of the novel proinflammatory supergene "intercrine" cytokine family. Annu. Rev. Immunol. 9:617-648.

5. Baggiolini, M., B. Dewald, and B. Moser. 1994. Interleukin-8 and related chemotactic cytokines-CXC and CC chemokines. Adv. Immunol. 55:97-179.

6. Taub, D.D., and J.J. Oppenheim. 1994. Chemokines, inflammation, and the immune system. Ther. Immunol. 1:229-242.

7. Baggiolini, M. 1993. Chemotactic and inflammatory cytokines: CXC and CC proteins. In The Chemokines: Biology of the Inflammatory Peptide Supergene Family. I.J.D. Lindley, J. Westwick, and S. Kunkel, editors. Adv-ExpMed. Biol. Plenum Press, New York. 1-11.

8. Brennan, F.M., C.O.C. Zachariae, D. Chantry, C.G. Larsen, M. Turner, R.N. Maini, K. Matsushima, and M. Feldmann. 1990. Detection of IL-8 biological activity in synovial fluids from patients with rheumatoid arthritis. Eur. J. Immunol. 20:2141-2144.

9. Gillitzer, R., R. Berger, V. Mielke, C. Muller, K. Wolff, and G. Stingl. 1991. upper keratinocytes of psoriatic skin lesions express high levels of NAP-1/ IL-8 mRNA in situ. J. Invest. Dermatol. 97:73-79.

10. Piechl, P., M. Ceska, F. Effenberger, G. Haberhauer, H. Broell, and I.J.D. Lindley. 1991. Presence of NAP-1/IL-8 in synovial fluids indicates a possible pathogenic role in rheumatoid arthritis. Scand. J. Immunol. 34:333-339.

11. Rampart, M., J. Van Damme, L. Zonnekeyn, and A.C. Herman. 1989. Granulocyte chemotactic protein/interleukin-8 induces plasma leakage and neutrophil accumulation in rabbit skin. Am. J. Pathol. 135:21-25.

12. Foster, S.J., D.M. Aked, J.M. Schroder, and E. Christophers. 1989. Acute inflammatory effects of a monocyte-derived neutrophil-activating pep- 
tide in rabbit skin. Immunol. 67:181-183.

13. Colditz, I.G., R.D. Zwahlen, and M. Baggiolini. 1990. Neutrophil accumulation and plasma leakage induced in vivo by neutrophil-activating peptide-1. J. Leuk. Biol. 48:129-137.

14. Swensson, O., C. Schubert, E. Christophers, and J.M. Schroder. 1991. Inflammatory properties of neutrophil-activating peptide-1/interleukin-8 (NAP-1/IL-8) in human skin: a light- and electron-microscopic study. J. Invest. Dermatol. 96:682-689.

15. Harada, A., N. Sekido, K. Kuno, M. Akiiyama, T. Kasahara, I. Nakanishi, N. Mukaida, and K. Matsushima. 1993. Expression of recombinant rabbit IL-8 in Escherichia coli and establishment of the essential involvement of IL-8 in recruiting neutrophils into lipopolysaccharide-induced inflammatory site of rabbit skin. Int. Immunol. 5(6):681-690.

16. Schroder, J.M., U. Mrowietz, E. Morita, and E. Christophers. 1987. Purification and partial biochemical characterization of a human monocytederived, neutrophil-activating peptide that lacks interleukin-1 activity. J. Immunol. 139:3474-3483.

17. Carveth, H.J., J.F. Bohnsack, T.M. McIntyre, M. Baggiolini, S.M. Prescott, and G.A. Zimmermann. Neutrophil activating factor (NAF) induces polymorphonuclear leukocyte adherence to endothelial cells and to subendothelial matrix proteins. Biochem. Biophys. Res. Commun. 162:387-393.

18. Djeu, J.Y., K. Matsushima, J.J. Oppenheim, K. Shiotsuki, and D.K. Blanchard. 1990. Functional activation of human neutrophils by recombinant monocyte-derived neutrophil chemotactic factor/IL-8. J. Immunol. 144:22052210.

19. Brandt, E., F. Petersen, and H.-D. Flad. 1992. Recombinant tumor necrosis factor- $\alpha$ potentiates neutrophil degranulation in response to host defense cytokines neutrophil-activating peptide 2 and IL- 8 by modulating cAMP levels. J. Immunol. 149:1356-1364.

20. Larsen, C.G., A.O. Anderson, E. Appella, J.J. Oppenheim, and K. Matsushima. 1989. The neutrophil-activating protein (NAP-1) is also chemotactic for T lymphocytes. Science (Wash. DC). 243:1464-1466.

21. Bacon, K.B., and R.D. R. Camp. 1990. Interleukin(IL)-8-induced via in vitro human lymphocyte migration is inhibited by cholera and pertussis toxins and inhibitors of protein kinase C. Biochem. Biophys. Res Commun. 169:10991104.

22. Wilkinson, P.C., and I. Newman. 1992. Identification of IL-8 as a locomotor attractant for activated human lymphocytes in mononuclear cell cultures with anti-CD3 or purified protein derivative of Mycobacterium tuberculosis. $J$. Immunol. 149:2689-2694.

23. Taub, D.D., K. Conlon, A.R. Lloyd, J.J. Oppenheim, and D.J. Kelvin. 1993. Preferential migration of activated $\mathrm{CD} 4^{+}$and $\mathrm{CD} 8^{+} \mathrm{T}$ cells in response to MIP-1 $\alpha$ and MIP-1ß. Science (Wash. DC). 260:355-358.

24. Taub, D.D., and J.J. Oppenheim. 1993. Review of the chemokine meeting: The third international symposium of chemotactic cytokines. Cytokine. 5: 175-179.

25. Murphy, W.J., M. Bennett, M.R. Anver, M. Baseler, and D.L. Longo. 1992. Human-mouse lymphoid chimeras: host-vs-graft and graft-vs-host reactions. Eur. J. Immunol. 22:1421-1427.

26. Taub, D.D., A.R. Lloyd, J.M. Wang, and J.J. Oppenheim. 1994. the $\alpha$ and $\beta$ chemokine superfamily. In current Protocols in Immunology. J.E. Coligan et al., editors. Greene Publishing Associates and Wiley-Interscience, New York.

27. Falk, W.R., R.H. Goodwin, Jr., and E.J. Leonard. 1980. A 48-well microchemotaxis assembly for rapid and accurate measurement of leukocyte migration. J. Immunol. Methods. 33:239-247.

28. Taub, D.D., A.R. Lloyd, K. Conlon, Matsushima, D.J. Kelvin, and J.J. Oppenheim. 1993. Recombinant human interferon-inducible protein-10 (IP-10) is a chemoattractant for human monocytes and $\mathrm{T}$ lymphocytes and promotes $\mathrm{T}$ cell adhesion to endothelial cells. J. Exp. Med. 177:1809-1814.

29. Pilaro, A.M., T.J. Sayers, K.L. McCormick, C.W. Reynolds, and R.H. Wiltrout. 1990. An improved in vitro assay to quantitate chemotaxis of rat peripheral blood large granular lymphocytes (LGL). J. Immunol. Methods. 135: 213-223.

30. West, B.C., A.S. Rosenthal, N.A. Gelb, and H. Kimball. 1974. Separation and characterization of human neutrophil granules. Am. J. Pathol. 77:4166.

31. Wright, D.G., D.A. Bralove, and J.I. Gallin. 1977. The differential mobilization of human neutrophil granules. Effects of phorbol myristate acetate and ionophore A23187. Am. J. Pathol. 87:273-284.

32. Gallin, J.I., D.G. Wright, and E. Schiffman. 1978. Role of secretory events in modulating human neutrophil chemotaxis. J. Clin. Invest. 62:13641374.

33. Crouch, S.P.M., and J. Fletcher. 1992. Effect of ingested pentoxifylline on neutrophil superoxide anion production. Infect. Immun. 60:4504-4509.

34. Talalay, P., W.H. Fishman, and C. Huggins. 1946. Chromogenic substrates. II. Phenolphthalein glucuronic acid as substrate for the assay of glucuronidase activity. J. Biol. Chem. 166:757-772.

35. Wroblewski, F. and J.S. LaDue. 1955. LDH activity in blood. Proc. Soc. Exp. Biol. Med. 90:210-221.

36. Baggiolini, M., J.G. Hirsch, and C. DeDuve. 1969. Resolution of granules from rabbit heterophil leukocytes into distinct populations by zonal sedi- mentation. J. Cell Biol. 40:529-535.

37. Murphy, W.J., D.D. Taub, M. Anver, J.J. Oppenheim, D.J. Kelvin, and D.L. Longo. 1994. Human RANTES induces the migration of human T lymphocytes into the peripheral tissues of mice with severe combined immune deficiency (SCID). Eur. J. Immunol. 24(8):1823-1827.

38. Taub, D.D., P. Proost, W.J. Murphy, M. Anver, D.L. Longo, J. Van Damme, and J.J. Oppenheim. 1995. Monocyte chemotactic protein-1 (MCP-1) -2 , and -3 are chemotactic for human T lymphocytes. J. Clin. Invest. 95:13701376

39. Gallin, J.I., J.A. Sandler, D.G. Wright, V.C. Magnaniello, and M. Vaughn. 1976. Calcium ionophore A23187 increases leukocyte $\mathrm{CA}^{++} \mathrm{ex}-$ changes, inhibits chemotaxis, mobilizes neutrophil specific granules and increases cAMP. Fed. Proc. 35:492(1588).

40. Sozzani, S., W. Luini, M. Molino, P. Jilek, B. Bottazzi, C. Cerletti, K Matsushima, and A. Mantovani. 1991. The signal transduction pathway in volved in the migration induced by a monocyte chemotactic cytokine. J. Immunol. 147:2215-2226.

41. Goldstein, I.M., S. Hoffstein, J.I. Gallin, and G. Weissmann. 1973. Mechanisms of lysosomal enzyme release from human leukocytes: Microtubule assembly and membrane fusion induced by a component of complement. Proc. Natl. Acad. Sci. USA. 70:2916-2920.

42. Becker, E.L., H.J. Showell, P. M. Henson, and L.S. Hsu. 1974. The ability of chemotactic factors to induce lysosomal enzyme release. I. The characteristics of the enzyme release, importance of surfaces and the relation of enzyme release to chemotactic responsiveness. J. Immunol. 12:2047-2054.

43. Zurier, R.B., S. Hoffstein, and G. Weissmann. 1973. Cytochalasin B: Effect of lysosomal enzyme release from human leukocytes. Proc. Natl. Acad. Sci. USA. 70:844-848.

44. Showell, H.J., R.J. Freer, S.H. Zigmond, E. Schiffmann, S. Aswankumar, B. Corcoran, and E.L. Becker. 1976. The structure activity relations of synthetic peptides as chemotactic factors and inducers of lysosomal enzyme secretion for neutrophils. J. Exp. Med. 143:1154-1169.

45. Becker, E.L. 1976. Some interrelations of neutrophil chemotaxis, lysosomal enzyme secretion, and phagocytosis as revealed by synthetic peptides. Am. J. Pathol. 85:385-394.

46. Bainton, D.F., J.L. Ullyot, and M.G. Farquhar. 1971. The development of neutrophilic polymorphonuclear leukocytes in human bone marrow: Origin and content of azurophil and specific granules. J. Exp. Med. 134:907-1000.

47. Bainton, D.F., and M.G. Farquhar. 1966. Origin of granules in polymorphonuclear leukocytes: Two types derived from opposite faces of the Golgi complex in developing granulocytes. J. Cell Biol. 28:277-289.

48. Bainton, D.F., and M.G. Farquhar. 1968. Differences in enzyme content of azurophil and specific granules of polymorphonuclear leukocytes. I. Histochemical staining of bone marrow smears. J. Cell Biol. 39:286-298.

49. Bainton, D.F., and M.G. Farquhar. 1968. Differences in enzyme conten of azurophil and specific granules of polymorphonuclear leukocytes. II. Cytochemistry and electron microscopy of bone marrow cells. J. Cell Biol. 39:299312

50. Spitznagel, J.K., F.G. Dalldorf, M.S. Leffell, J.D. Folds, I.R.H. Welsh, M.H. Cooney, and L.E. Martin. 1974. Character of azurophil and specific granules purified from human polymorphonuclear leukocytes. Lab. Invest. 30:774 785

51. Bainton, D.F. 1973. Sequential degranulation of the two types of polymorphonuclear leukocyte granules during phagocytosis of microorganisms. $J$. Cell Biol. 58:249-261.

52. Leffell, M.S., and J.K. Spitznagel. 1974. Intracellular and extracellular degranulation of human polymorphonuclear azurophil and specific granules induced by immune complexes. Infect. Immun. 10:1241-1249.

53. White, J.G., and R.D. Estensen. 1974. Selective labilization of specific granules in polymorphonuclear leukocytes by phorbol myristate acetate. Am. J. Patho. 75:45-60.

54. Estensen, R.D., J.G. White, and B. Holmes. 1974. Specific degranulation of human polymorphonuclear leukocytes. Nature (Lond.). 248:347-348

55. Goldstein, I.M., S.T. Hoffstein, and G. Weissmann. 1975. Mechanisms of lysosomal enzyme release from human polymorphonuclear leukocytes: ef fects of phorbol myristate acetate. J. Cell Biol. 66:647-652.

56. Baggiolini, M., C. DeDuve, P.L. Masson, and J.F. Heremans. 1974. Association of lactoferrin with specific granules in rabbit heterophil leukocytes. $J$. Exp. Med. 131:559-572

57. Kudo, C., T. Yamashita, A. Araki, M. Terashita, T. Watanabe, M. Atsumi, M. Tamura, and F. Sendo. 1993. Modulation of in vivo immune response by selective depletion of neutrophils using a monoclonal antibody, RP-3. I. In hibition by RP-3 treatment of the priming and effector phases of delayed type hypersensitivity to sheep red blood cells in rats. J. Immunol. 150:3728-3738.

58. Kudo, C., T. Yamashita, M. Terashita, and F. Sendo. 1993. Modulation of in vivo immune response by selective depletion of neutrophils using a monoclonal antibody, RE-3. II. Inhibition by RP-3 treatment of mononuclear leukocyte recruitment in delayed-type hypersensitivity to sheep red blood cells in rats. J. Immunol. 150:3739-3746.

59. Lewis, R.A., and K.F. Austin. 1984. The biologically active leukotrienes. J. Clin. Invest. 73:889-897. 